\title{
WZMOCNIENIA LEKSYKALNE W TŁUMACZENIACH POEZJI DZIECIĘCEJ
}

Zarys treści: Artykuł poświęcony jest analizie wybranych wierszy K. Czukowskiego i ich przekładów na język polski przez pryzmat przekazu stopnia dosadności leksykalnej - wzmocnienia leksemów (bądź tonowania znaczeń). Jak się okazuje, płaszczyzna semantyki, jej „jakość”, może potencjalnie wpływać na odbiór tekstu wtórnego w stosunku do pierwotnego, zwłaszcza jeśli implikowanym czytelnikiem jest dziecko.

Słowa kluczowe: tłumaczenie poezji; semantyka; recepcja tekstu; wzmocnienia leksykalne

\section{Przekład powinien być przekładem czy alter ego oryginału?}

A. Popovič, analizując przekład w świetle teorii dzieła literackiego, zaznacza, że przekładowi stawiany jest warunek, by był on „funkcją oryginału”, czyli jego reprezentantem. Fałszywe są natomiast funkcje przekładu „bycia pierwowzorem", występowania jako utwór, który ukrywa swoje pochodzenie. $\mathrm{Z}$ drugiej strony „przekład powinien przede wszystkim reprezentować niezmienność oryginału i [...] stać się wariantem" (Popovič 2009: 104). Pamiętać jednak należy, że „żaden język nie jest tak prosty, jak proste jest uporządkowane myślenie" (Paepcke 2009: 337).

Zdaniem F. Paepcke

sztywna analiza systemowa w dziedzinie języka zawsze jest wiwisekcją, ponieważ każdy język jest niesystematycznym tworem systemowym. Dlatego mizerne rezultaty musi przynieść wszelka próba systematyzującego porządkowania, mającego za przedmiot język, z jego rozkołysanym rytmem i zawiłą mechaniką reguł; kto podejmuje tego rodzaju wysiłki weryfikacyjne i falsyfikacyjne, stara się wyeliminować 
sprzeczności, które tkwią w każdym języku - i mniema, że tym sposobem uzyskał naukową prawdę o języku (Paepcke 2009: 337).

Czynność przekładu opiera się zatem, zdaniem badacza, na specyficznych operacjach korelowania tekstu w języku oryginału i w języku przekładu. Tekst zaś nie stanowi sumy tworzących go elementów, ale skomplikowanych, powiązanych ze sobą relacji (Paepcke 2009: 337-338). Wspomniany badacz przywołuje myśl H. M. Gaugera, który zauważa, że w każdym tekście splatają się wzajemnie elementy językowe, komponenty językowe i pozajęzykowe. Komponenty językowe pełnią funkcję „wehikułu komponentów pozajęzykowych, tak że tekst jest również tworem pozajęzykowym, który przeszedł przez medium języka" (Paepcke 2009: 339). Każdy tekst odnosi się ponadto, zdaniem Gaugera, do jakiejś sytuacji kulturowej, którą spaja określony kontekst rozumiany jako połączenie elementów semantycznych, syntaktycznych, modalność poszczególnych elementów tekstu. Jednostkowość połączenia tych relacji wiąże się z niepowtarzalną indywidualnością każdego tekstu. Badacz podkreśla również, że podstawową zasadą tekstu jest jego nadsumatywność, która jest czymś więcej niż sumą wszystkich partii czy form tekstu. Takie rozumienie znaczenia tekstu nie neguje zasady autonomii mniejszych form. Nie oznacza, że mniejsze jednostki tekstualne są absorbowane przez większe. Te mniejsze nie rozmywają się bowiem w kształcie całości. Stanowią zawsze „cząstkową całostkę” pozostającą w relacji do nadsumatywnej treści. Stosunek mniejszej jednostki tekstualnej do większej nie polega jednak na prostej sumacji przypominającej relację addycyjną na zasadzie „jeden obok drugiego" czy ,jedno w drugim”. Mogą być one bowiem na płaszczyźnie całego tekstu w relacji wzajemnego dopasowania czy przyporządkowania, co przy uwzględnieniu ich występowania w szerszych ramach wiąże się z określonymi konsekwencjami treściowymi, z procesem przekazu kierowanym do odbiorcy tekstu. Uwzględnienie szerszej całości stanowi zabezpieczenie dla rozumienia. Rozumiany tekst nie tylko dostarcza informacji, ale jest również przekazem, który stanowi dla słuchacza, czytelnika czy tłumacza treść świadomościową. Steruje odbiorcą. Jest aktem dokonującym się pomiędzy autorem a czytelnikiem (tłumaczem) i sterującym nie tyle jego wiedzą, ile świadomością. Poszczególne elementy językowe są bowiem „współobecne w horyzoncie świadomości". W takim rozumieniu tekst transformuje wiedzę, którą czytelnik już ma, przez przeniesienie sposobu doświadczania, myślenia czy przekładania w oparciu o świadomościową treść ${ }^{1}$. Rozumienie przekazu

${ }^{1} \mathrm{O}$ wiedzy uprzedniej patrz też Lewicki 2000: 29. 
nie może zatem ograniczać tylko do rozumienia tekstu. Musi wciągnąć w ten proces czytelnika (tłumacza), który chce rozumieć (Paepcke 2009: 339-341). Jak twierdzi F. Paepcke, tłumacz nie przekłada języka, lecz tekst. Nie przekłada znaczenia słów, lecz myśl, którą sam zrozumiał, współpodążając za rozumieniem autora oryginału. $\mathrm{W}$ ten sposób oddaje stany rzeczy, do których odnosi się myśl autora.

Podstawowy problem translacji polega nie na ustawianiu słów (czy ich grup) w szereg, lecz na wzbogacaniu całości, nastawionym na identyczność [...]. W translacji, która przechodzi od języka do języka, na płaszczyźnie tekstualnej musi zachodzić identyczność semantyczna - zatem identyczność myśli. Urzeczywistnianie identyczności w przekładzie opiera się na tym, że wszelka transformacja potrzebuje substancji - i na niej się dokonuje (Paepcke 2009: 343).

Celem niniejszej analizy jest porównanie wybranych wierszy K. Czukowskiego i ich przekładów na język polski przez pryzmat przekazu wspomnianej „substancji”. Jak płaszczyzna semantyki wpływa na potencjalną identyczność myśli odbiorców tekstu pierwotnego i wtórnego? Czy i w jakim zakresie stopień dosadności leksykalnej - wzmocnienia leksemów (bądź tonowania) może wpływać na odbiór tekstu przez czytelnika?²

Punktem wyjścia do dalszych rozważań niech będzie poniższa para tekstów:

- И сейчас же к нему из-за елки

Выбегают мохнатые волки (А)

- I wtedy z leśnej gestwiny

Straszne wilki wyskoczyły (Ap)

Poza oczywistym spostrzeżeniem, że włochaty to nie to samo, co strasz$n y$, w rozpatrywanej kwestii nie można pominąć implikowanego odbiorcy. Tekst oryginału, tworzony przez jego autora, kierowany do założonego adresata jest przez działania tłumacza $\mathrm{z}$ udziałem stworzonego przezeń tekstu przeznaczony dla innego czytelnika. Zmienia się zatem twórca, zmienia się „substancja”, zmienia się też odbiorca - uczestnik innej kultury. Patrząc na powyższe cytaty, trudno jednak nie dostrzec jednego - specyfiki adresata

${ }^{2}$ O tendencjach deformujących, m.in. uszlachetnianiu, zubożaniu jakościowym, patrz: Berman 2009: 253-264, o degradacji tekstu literackiego por. Bednarczyk 1993: 73-85, o zakłóceniach komunikacji w przekładzie por. Manasterska-Wiącek 2010: 165-174. 
analizowanych wierszy. Jest to dziecko. Czytelnik, który ma określoną naturę niezależnie od umocowania w kulturze. Dziecko, dostrzegające nawet najdrobniejsze szczegóły, odznacza się wrażliwością w kontakcie z otoczeniem, ale i z dziełem literackim ${ }^{3}$. Z uwagi na niedoskonałą znajomość systemu językowego i stopniowe poznawanie leksykonu języka ojczystego dziecko odbiera poznawane leksemy ze szczególną precyzją, często rzecz jasna nieobejmującą całości użyć określonych jednostek. Oczywiście przed odbiorcą tekstu literackiego stoi zwykle jeden tekst - oryginał albo przekład. Dziecko nie ma w związku z tym okazji do konfrontacji obu tekstów ${ }^{4}$. Krytyk przekładu dzięki proponowanej analizie może jednak określić potencjalny wpływ rozwiązań translatorycznych na odbiór tekstu, a w tym zagadnieniu wzmocnienia leksykalne są sprawą niezwykle istotną. Jak się wydaje, z punktu widzenia dziecka przymiotnik straszny w przekładzie jest wyrazem, który z założenia będzie wpływał silniej na emocje czytelnika niż wyróżniony w oryginale. Straszny - to 1. 'wzbudzający strach, przerażenie, grozę, przejmujący lękiem, przerażający', 2. 'bardzo zły, okropny', 3. 'bardzo duży, bardzo intensywny, ogromny, wielki, niezmierny' (SJP). Wyraz, na który zdecydował się tłumacz, wiąże się $\mathrm{z}$ doznaniami nieprzyjemnymi dla dziecka, których malec nie lubi. Znacznie silniej może w związku z tym wpłynąć na jego reakcję.

O właściwościach wyrazu w tekście pisze A. Popovič. Różnicę między wartością wyrazu w oryginale a wartością wyrazu w przekładzie określa on jako przesunięcie wyrazu. Porównanie stylistycznych właściwości wyrazu wskazują na ewentualne różnice między tekstem wyjściowym a docelowym (Popovič 2009: 94).

Skonfrontujmy inną parę przykładów:

- А в море высокая ходит волна, Сейчас Айболита проглотит она (А)

- Toczy się fala wysoka, Pochłonie ich w mgnieniu oka (Ap)

Wyróżnione jednostki pozostają $\mathrm{w}$ stosunku do siebie $\mathrm{w}$ innych relacjach niż w przykładzie zaprezentowanym powyżej (мохнатьй - straszny). Dotyczą w zasadzie podobnej czynności - w obu tekstach istnieje zagrożenie, że doktor Nicnieboli zginie w odmętach oceanu. Jednak проглотить to

${ }^{3}$ Por. Manasterska-Wiącek 2009: 13-29.

${ }^{4}$ Dziecko, jak większość odbiorców, również tych dojrzałych, nie ma w ogóle świadomości istnienia pierwowzoru - więcej zob. Lewicki 2000. 
'глотая, пропустить в пищевод' (BTS), podczas gdy pochłonać - 1.'wciągnąć w siebie, wessać do wnętrza, wchłonąć'; 2. 'zjeść, wypić coś łapczywie, w dużych ilościach' (SJP). Przyznajmy, że leksem w tekście docelowym ma potencjał silniejszego, bardziej wymownego oddziaływania na odbiorcę, zwłaszcza dziecięcego, którego pokłady wyobraźni są nieporównywalnie większe niż u dojrzałego odbiorcy.

W ramach rozpatrywania problemu wzmocnień leksykalnych warto również zwrócić uwagę na przypadki rozszerzenia znaczeń w tekście wtórnym, jak w poniższym przykładzie:

- И одно только слово твердит Айболит: Лимпопо, Лимпопо, Лимпопо! (A)

- Pokrzykuje sobie, śpiewa Nicnieboli: Limpopo, Limpopo, Limpopo-po-po! (Ap)

Zaznaczone leksemy nie mają w słowniku kwalifikatorów stylistycznych, co oznacza, że można je uznać za neutralne. A jednak kiedy bohater wierszyka powtarza Limpopo i w to miejsce bohater drugiego wiersza pokrzykuje, śpiewa Limpopo, obserwujemy przypuszczalnie dosadniejszy wpływ wyróżnionych komponentów na odbiorcę przekładu przez użycie bardziej obrazowych jednostek. W kontakcie z przekładem można odnieść wrażenie kontaktu z dźwiękiem, co nie jest udziałem czytelnika oryginału. Powtarzanie samego leksemu jest w przekładzie dodatkowo wzmocnione przez zabieg powtórzenia ostatniej sylaby (Limpo-po-po).

Takie wzmocnienie leksykalne uzyskane drogą rozszerzenia semantycznego można dostrzec i w kolejnym przykładzie:

- Вот и вылечил он их, Лимпопо, Вот и вылечил больных Лимпопо! (А)

- Dzięki ci, dzięki doktorze! Limpopo! Już sa zdrowi wszyscy chorzy! Limpopo! (Ap)

Jak widzimy, wzmocnienie leksykalne stanowić może i określenie precyzujące słowo nadrzędne, będące przeniesieniem z tekstu wyjściowego. Przekład jest przez taki zabieg bardziej szczegółowy, daje przy tym wzmocniony obraz wyjściowego wyrażenia. Dziecko wie, że to wszyscy chorzy zostali wyleczeni - wszyscy bez wyjątku.

Podobnym nasileniem w ramach rysowanego w przekładzie obrazu będzie w niektórych przypadkach użycie liczby mnogiej zamiast pojedynczej: 
- Приходи к немулечиться

И корова, и волчии,

Ижучок, и червячок,

Имедведииа! (Т)

- Śpiesza tam, gdy chca być zdrowi,

Wilk $z$ wilczyca, biegna krowy,

Pełzną żuczki, leca muszki,

Ida państwo niedźwiedziowie (Tp)

Poza oczywistą zmianą w sferze obrazowości ewidentnie przed odbiorcą przekładu rysują się wzmocnione prezentacje leksykalne - zwierzątek jest więcej, więcej z nich może wyleczyć Doktor, „materia” wykorzystywana przez twórcę przekładu jest w tym aspekcie inna niż oryginał. Ale wyróżnia ją jeszcze jeden zabieg, a mianowicie każdej grupie zwierząt towarzyszy wyrażona explicite czynność. Ona również wzmacnia za każdym razem pośrednio i siłę wyrazu rzeczowników. Spostrzeżenie to jednak podlega już analizie syntaktycznej, która jest odrębnym spojrzeniem na podjęte zagadnienie.

Przy okazji leksemów dodanych w przekładzie warto przyjrzeć się następującym cytatom:

- И принесли к нему зайку, Такого больного, храмого (А)

- Przyniesiono go. Okropność! Chory byt, kulat biedaczek (Ap)

- А в лицо ему ветер, и снег и град (A)

- Po twarzy go chłoszcze wiatr z gradem i śniegiem (Ap)

Oprócz jawnej transformacji składniowej na płaszczyźnie wzmocnień leksykalnych zabiegi tłumacza też nie pozostają bez znaczenia. Zauważmy - w tekście wtórnym pojawiają się nieneutralne leksemy, które czyniłyby już przez sam fakt ich dodania plan leksykalny pełniejszym. Są to ponadto wyrazy, które mają wymiar emocjonalny w dziecięcym odbiorze. Okropność jest wprawdzie rzeczownikiem traktowanym przez słownik jako wyraz neutralny stylistycznie, jednak jego znaczenie 'cecha tego, co jest okropne; bycie okropnym, strasznym' (SJP) nie może być obojętne dla percepcji dziecięcej. Podobnie czasownik chłostać - 'o wietrze, deszczu itp.: bić, uderzać gwałtownie, zacinać' (SJP) - jak widzimy, hasło słownikowe wartościuje leksem w stosunku do zacinać, traktując go jako nacechowany stylistycznie, a w związku 
z tym można tę jednostkę uznać niewątpliwie za wzmocnioną w odniesieniu do neutralnej. Problem ten prowadzi do pewnego spostrzeżenia. Otóż zagadnienie wzmocnień leksykalnych $\mathrm{w}$ relacji oryginał-przekład może być rozpatrywane nie tylko międzysystemowo, ale i wewnątrzsystemowo. Załóżmy hipotetyczne rozwiązanie tłumacza, że wyposaża on swój tekst w rzeczownik zacina. Konsekwencje takiego zabiegu w stosunku do oryginału są niewielkie, oceniając je przez pryzmat odbioru. Czyż nie taka treść, wyrażona w ukrytym planie, wynika ze zdania pierwotnego? Gdyby hipotetyczny leksem został użyty w tekście wyjściowym, trudno by było klasyfikować to dodanie jako wzmocnienie leksykalne. Jednak wiatr chłoszcze w przekładzie - a to jest czasownik wzmocniony w stosunku do zakładanego, presupowanego w oryginale ekwiwalentu zacina. Tłumacz, co podkreśla A. Popovič, musi „ważyć”, „dozować”, „prowadzić grę" „z elementarnymi właściwościami stylistycznymi, gdyż to one są dla niego najbardziej decydujące i reprezentatywne ze względu na konstrukcje tekstu" (Popovič 2009: 95). Oczywiście jest to możliwe

pod warunkiem nadbudowy współdecydującej o tym, który z możliwych paradygmatów tłumacz wybierze, która z danych właściwości wyrazu będzie najbardziej znamienna i najodpowiedniejsza. Tłumacz pracuje nad tym na tle oryginału i jego kontekstu (Popovič 2009: 95).

Kolejna para:

- Таня - Ваня задрожали - Бармалея увидали. Он по Африке идет, на всю Африку поет (В)

- Oto Czarny Piotr nadchodzi, pewnie dobrze się wygłodzit. Zbliża się, a to, co śpiewa, w całej Afryce rozbrzmiewa (Bp)

- Посмотри, в аэроплане кто-то по небулетит. Это доктор, это доктор, добрый доктор Айболит (В)

- Patrz, ktośleci samolotem i przybliża się powoli. To pan doktor, to pan doktor, Dobry doktor nasz, Ojboli! (Bp)

Być może wyróżnione leksemy nie podlegałyby analizie, gdyby nie fakt, że implikowanym odbiorcą utworów jest właśnie dziecko. Opisywany m.in. w pracach J. Piageta egocentryzm dziecięcy ma w tym aspekcie szczególne znaczenie. Dziecko dopasowuje do siebie informacje na temat wszystkiego, co poznaje. Uświadamia sobie jedynie własny punkt widzenia i nie podejmuje 
prób zrozumienia zjawisk z perspektywy innej niż własna (Smykowski 2005: 189). Świadomi tej właściwości percepcji świata przez dziecko prześledźmy interesujące nas modyfikacje. Idzie czy leci to czynności, które dziecko biernie obserwuje. Odpowiadające im czasowniki zbliża się, przybliża się są czynnościami, w których dziecko staje się obiektem. Malec oceniający z własnej perspektywy otaczającą go rzeczywistość zapewne odbierze obserwowany ruch jako ukierunkowany na niego. To do dziecka przybliża się Czarny Piotruś czy Doktor Ojboli. I w tym wymiarze - optyki dziecięcego odbioru, włączenia czytelnika do zabawy jako jej czynnego uczestnika - tekst przekładu jest dosadniejszy od oryginału, a opisana obserwacja to przykład wzmocnienia leksykalnego.

W wyróżnionym obszarze natury dziecka, prezentowanych przez nie postaw, przyjrzyjmy się i następnym cytatom:

- И теперь он больной и хромой, Маленький заинька мой! (A)

- Chory jest, chodzić nie może Synuś mój mały, o Boże! (Ap)

- Что станется с ними, с больными, С моими зверями тесными (A)

- Cóż z chorymi dziećmi będzie, Co mnie oczekuja wszędzie? (Ap)

Nie w sferze stylistyki, rejestrów czy poziomów języka, ale właśnie na płaszczyźnie dziecięcego odbioru będziemy szukać (nie)równości wyrażeń leksykalnych. I w tym świetle są one rzeczywiście nierównoprawne. Świat słownictwa dziecięcego to świat deminutywny. Dziecko lubi słuchać zdrobnień, nimi też posługuje się we własnym języku. Każde zdrobnienie w stosunku do leksemu neutralnego będzie wzmocnieniem leksykalnym - silniej w wymiarze emocjonalnym odbieranym przez czytelnika. Oprócz tego zaznaczone wyrazy różnią się i samym znaczeniem. Synuś czy dzieci zamiast $z a-$ jaczka lub zwierząt są bliższe założonemu adresatowi. To on jest na co dzień dzieckiem, to on jest synkiem czy córeczką. Jak pisze A. Baluch, dziecko otacza się kręgami - ten pierwszy to bliscy mu ludzie, opiekunowie, rzeczywiste zwierzątka, drugi to postaci fikcyjne, m.in. bohaterowie literaccy (Baluch 1989: 195). Synuś i dzieci stanowią niejako kompilację tego, co bliskie dziecku w sferze fikcji, i tego, co zna i czego doświadcza w realnym świecie. W efekcie leksemy są wzmocnione, potencjalnie silniej mogą podziałać na dziecięcy 
odbiór. W tym też wyraża się przytaczana już myśl H.M. Gaugera, że przekład „steruje świadomością” odbiorcy (Paepcke 2009: 340).

Spójrzmy na poniższą parę przykładów:

- И рышут по дороге слоны и носороги

И говорят сердито: «Что ж нету Айболита»? (А)

- Szukaja go na ladzie całe stada słoni, Bo może gdzieś zabładził, gdzie jest Nicnieboli? (Ap)

Ciekawy przykład, w którym, gdyby rozpatrywać wzmocnienia leksykalne na zasadzie ,jeden do jednego", stado słoni byłoby ujęciem mogącym w sposób bardziej wyrazisty wpłynąć na odbiór. Jednak w tekście wtórnym brakuje rzeczownika носорогu, со z kolei też daje wrażenie stada w sensie mnogości obiektów. Nie można zapomnieć, że wymogi formalne tekstu poetyckiego w sposób szczególny decydują o pewnych rozwiązaniach. Zacytowane rozwiązanie należy uznać za celne posunięcie translatorskie, niemodyfikujące w istotny sposób wrażenia odbiorczego.

Jak można przypuszczać, nie zawsze jest tak, że w tekście wtórnym leksemy będą oddawane jako wzmocnione. Bywają i sytuacje odwrotne. Przeciwwagą dla wzmocnień leksykalnych będą oczywiście przypadki osłabienia leksykalnego, tonowania znaczeń w przekładzie w stosunku do oryginału.

Ciekawym przykładem takiego zabiegu jest imię tytułowego bohatera jednego z wierszy K. Czukowskiego - Айболит. Substantywizacja czasownika болит tworząca formację z wykrzyknieniem aŭ, które w języku oryginału wyraża m.in. ból, pozwala na wyprowadzenie znaczenia pojmowanego z punktu widzenia leczonych przez doktora zwierząt, które chorują, które coś boli. W przekładzie następuje zupełna zmiana tej optyki. Doktor nazywa się Nicnieboli, a zatem to z jego punktu widzenia wychodzi tłumacz, nadając mu imię. To doktor pomaga zwierzętom, za sprawą jego działania mieszkańcy lasu zdrowieją. To on powoduje, że nic ich nie boli. Wypada zaznaczyć, że Айболит powraca do czytelnika i w wierszu K. Czukowskiego Czarny Piotruś. Tu jednak został przetłumaczony jako Ojboli, adekwatnie do jednostki występującej w oryginale. Gdybyśmy chcieli ocenić pierwsze opisane rozwiązanie, należałoby $\mathrm{w}$ nim dostrzec osłabienie leksykalne. $\mathrm{Z}$ punktu widzenia dziecka stan nic nie boli jest neutralny w stosunku do oj! boli!

Przykładem stonowania w wymiarze znaczeniowym leksemów, a przez to niezaznaczających się na płaszczyźnie emocji odbiorcy przekładu, jest również poniższy fragment: 
- Ик полосатым бежит он тигрятам. И к бедным горбатым больным верблюжатам (А)

- Tygrysięta pręowane zostały także zbadane, Również wielbłodzięta małe - garby bardzo je bolały (Ap)

Przymiotnik w przekładzie jest wręcz pleonazmem, naddaniem leksykalnym. Wzmacnia określany rzeczownik, jednak na zasadzie przerysowania. Wielbłodziątka muszą być małe. Natomiast w oryginale te zwierzątka są oprócz tego biedne - 'nieszczęśliwe, wzbudzające litość, współczucie' (SJP), co zdecydowanie silniej dociera do umysłu i świadomości czytelnika.

Na podstawie dokonanej analizy można stwierdzić, że wzmocnienia leksykalne w omawianych przekładach zaobserwowano w rozmaitych relacjach:

- leksem zupełnie inny znaczeniowo niż w oryginale,

- leksem podobny semantycznie, ale o silniejszym zabarwieniu emocjonalnym,

- rozszerzenia leksykalne - dodanie leksemu do istniejącego w oryginale,

- zabiegi uszczegóławiające - dodanie leksemu, którego brak w oryginale, modyfikacja gramatyczna, np. liczba mnoga zamiast pojedynczej,

- dobór leksyki bliższej słownictwu implikowanego odbiorcy lub nakierowującej komunikat na niego, związanej z jego świadomością.

Wymienione relacje świadczą o konieczności analizy wzmocnień leksykalnych nie na poziomie leksemu, ale na poziomie tekstu. Ten bowiem jest płaszczyzną odbioru przez czytelnika. Na nim budowane są wrażenia i emocje. Pamiętać jednak należy, że na odczucie całości wpływają poszczególne elementy tekstu, nie można w związku z tym stronić od wnikania we wzajemną relację jednostek tłumaczenia, gdyż to $z$ nimi związana jest płaszczyzna nadrzędna - tekst. Pokrewną z tym sądem myśl wyraża A. Popovič: „,szersze powiązania nie stanowią istoty analizy, ale jedynie kontroluja poprawność danej decyzji tłumacza w zakresie wyboru środków wyrazu" (Popovič 2009: 96). Ocena ogólna wpływu wzmocnień leksykalnych na odbiorcę zależy od stosunku podjętych przez tłumacza kroków w tej mierze, od ich jakości i rozmiarów w tekście przekładu. Jak zaznacza F. Paepcke,

treść tekstu jako całości ma [...] pierwszeństwo przed pojedynczym słowem, a przejawem swobody w oddawaniu treści nie jest identyczność oryginału i przekładu, lecz dokładność czy precyzja, która dzięki równoważności czy też ekwiwalencji nie kostnieje, lecz zachowuje elastyczność i dynamiczność (Paepcke 2009: 344). 
Percepcja tekstu nie jest $\mathrm{w}$ związku $\mathrm{z}$ tym efektem wspomnianej na wstępie prostej sumacji, dodania do siebie „składowych”. Odbiór tekstu jest znacznie bardziej złożony. Co warto podkreślić - jest procesem, czyli pewnym ciągiem zmian rozwijającym się w czasie i mającym charakter przyczynowo-skutkowy.

Dziecięce wyobrażenia świata ${ }^{5}$, również tego proponowanego przez literaturę, budowane są między innymi przez wypełnienie leksykalne odbieranych przez malca komunikatów. Stąd niezwykle istotne wydaje się, na jakie rozwiązania zdecyduje się tłumacz. Zawartość leksykalna, niczym cegiełki, z których składa się pewna całość, buduje w umyśle dziecka syntetyczne obrazy, co znajduje odbicie na płaszczyźnie tekstu. Tekst jako kompleksowy komunikat oddziałuje na małego odbiorcę również w sferze emocji. Te zaś są bezpośrednio związane z semantyką. Przekazywane znaczenie bywa modyfikowane - oddane z sposób odbiorczo bardziej złożony lub prostszy. Mogą być to również rozwiązania związane ze wzmocnieniami lub stonowaniami leksykalnymi.

W konfrontacji oryginał-przekład wzmocnienia leksykalne jawią się jako istotny problem. Warto zaznaczyć raz jeszcze, że przedstawiona analiza pozwala na rozumienie omawianego zjawiska nie jako odpowiedniość leksykalną w relacji jeden do jednego, ale szerzej - jako wpływ leksyki na wzmocnienie (bądź osłabienie) odbioru. Jest zatem zjawiskiem obserwowanym na poziomie odbioru tekstu. Wzmocnienie leksykalne wiąże się zatem przez semantykę z modyfikacją w obszarze percepcji tekstu. Bywa, że wyrażane znaczenie jest źródłem potencjalnie innych emocji odbiorcy przekładu, niż było to w oryginale. $\mathrm{W}$ takim rozumieniu wzmocnienia leksykalne będą obserwowane w dwóch planach oddziaływania emocjonalnego - na płaszczyźnie ekspresyjnej - wewnątrz odbiorcy, wywołując u niego z założenia silniejsze przeżycia przez potencjalne umożliwienie wyrażania uczuć, emocji, uzewnętrzniania przeżyć, oraz na zewnątrz odbiorcy, na płaszczyźnie impresywnej - wpływając na określone reakcje czytelnika, powodując jego określone wrażenie. Płaszczyzna ekspresji urzeczywistnia się w związku z tym w samym odbiorcy, plan impresji natomiast jest działaniem na odbiorcę, odbiorca mu podlega, siła oddziaływania impresywnego znajduje się bowiem po stronie samego leksemu, który swoja siłą wpływa na wrażenie adresata. Jak pisze A. Popovič,

pojęcia przekładu nie tworzymy w warstwie języka, ale na płaszczyźnie wyższej w warstwie stylistycznej, czyli na tym poziomie, gdzie kształtuje się kompleksowa

\footnotetext{
Określenie zaczerpnięte z tytułu monografii B. Bonieckiej (2010).
} 
wartość wyrazu w tekście, w wypadku tekstu literackiego - wartość estetyczna (Popovič 2009: 94).

Czy wzmocnienia leksykalne mają wymiar pejoratywny? W analizowanym korpusie badawczym raczej nie. Nie każda bowiem modyfikacja staje się od razu wadą utworu. Należy pamiętać, że analizowane utwory to poezja, a ta z uwagi na wymogi formalne - rym, rytm oraz wiele innych uwarunkowań - kieruje się swoimi prawami. Generalna ocena rozwiązań translatorskich, jakimi są wzmocnienia leksykalne, może się jednak okazać znacznie trudniejsza, niejednoznaczna. Odbiór tekstu ma przecież charakter subiektywny oraz jednostkowy. Próbując uogólnić znaczenie wzmocnień leksykalnych, możemy stwierdzić, że nie mają one wpływu negatywnego, o ile nie modyfikują w sposób znaczący odbioru. W przeprowadzonej analizie można było spostrzec, że niejednokrotnie powodowały wręcz, że tekst stawał się bliższy dziecku. Niewątpliwie jednak wzmocnienia leksykalne mogą powodować nieadekwatność w stosunku do oryginału i w ten sposób, w zależności od tego, na ile zmieniają odbiór tekstu, można je różnie wartościować.

Przekład powinien być przekładem czy alter ego oryginału? Pytanie postawione na początku rozważań okazuje się nieprecyzyjne. Przekład zawsze będzie przekładem. Fakt, czy przy okazji stanie się alter ego oryginału, zależy już od talentu tłumacza. Rozważania niniejsze niech zakończą słowa G. Steinera.

Tłumacz ponosi odpowiedzialność za [...] przemieszczenie oraz zachowanie energii znaczenia. Przekład jest, i to nie tylko metaforycznie, aktem podwójnego księgowania; zarówno pod względem formalnym, jak i moralnym księgi muszą się zbilansować (Steiner 2009: 334).

Przynajmniej powinny, dodajmy.

\section{Literatura}

\section{Teksty źródłowe}

К. Чуковский

A - Айболит, http://lukoshko.net/chukovsk/chuk10.shtml (dostęp: 23 lipca 2013 r.).

В - Бармалей, http://www.stihi-rus.ru/1/chukovskiy/3.htm (dostęp: 8 sierpnia 2013 r.). 
T - Тараканище, http://textbook.keldysh.ru/tarakan/text.htm (dostęp: 23 lipca 2013 r.).

K. Czukowski

Ap - Doktor Nicnieboli, 1981, tłum. M. Dolińska, Moskwa.

Bp - Czarny Piotruś, tłum. W. Broniewski, http://jadrociemnosci.blogspot. com/2010/09/cotygodniowa-komentarzowka-7.html (dostęp: 8 sierpnia 2013 r.).

Tp - Karaluszysko, 1988, tłum. D. Wawiłow, Warszawa.

\section{Literatura naukowa}

Baluch A., 1989, „Bohater literacki w funkcji pośrednika”, [w:] Wychowanie Przedszkolne, nr 4, s. 195-201.

Bednarczyk, A., 1993, „Stopniowa degradacja tekstu w tłumaczeniu”, [w:] Przekład artystyczny. Strategie translatorskie, P. Fast (red.), t. 5, Katowice, s. 73-85.

Berman, A., 2009, „Przekład jako doświadczenie obcego”, [w:] Współczesne teorie przekładu. Antologia, P. Bukowski, M. Heydel (red.), Kraków, s. 247-264.

Boniecka, B., 2010, Dziecięce wyobrażenia świata, Lublin.

Lewicki, R., 2000, Obcość w odbiorze przekładu, Lublin.

Manasterska-Wiącek, E., 2010, „Kompetentny odbiorca poszukiwany, czyli jak zakłócić komunikację w przekładzie”, [w:] Przekład - Język - Kultura II, R. Lewicki (red.), Lublin, s. 165-175.

Manasterska-Wiącek, E., 2009, Polska poezja dla dzieci w przekładach na język rosyjski. Na podstawie wierszy Juliana Tuwima i Jana Brzechwy, Lublin.

Paepcke, F., 2009, „Rozumienie tekstu a przekład”, [w:] Współczesne teorie przekładu. Antologia, P. Bukowski, M. Heydel (red.), Kraków, s. 335-346.

Popovič, A., 2009, „Teoria przekładu w systemie nauki o literaturze”, [w:] Wspótczesne teorie przekładu. Antologia, P. Bukowski, M. Heydel (red.), Kraków, s. 87-106.

Smykowski, B., 2005, „Wiek przedszkolny. Jak rozpoznać potencjał dziecka”, [w:] Psychologiczne portrety człowieka. Praktyczna psychologia rozwojowa, A.I. Brzezińska (red.), Gdańsk, s. 165-206.

Steiner, G., 2009, „Ruch hermeneutyczny”, [w:] Współczesne teorie przekładu. Antologia, P. Bukowski, M. Heydel (red.), Kraków, s. 327-334.

\section{Słowniki}

SJP - Słownik języka polskiego, M. Szymczak (red.), t. 1-3, Warszawa 1989.

BTS: БТС - Большой толковый словарь русского языка, С.А. Кузнецов (red.), Санкт-Петербург 2000. 


\section{Lexical emphasis in children's poetry translation}

\section{Summary}

The article is devoted to the analysis of the selection of poems by K. Czukowski and their translations into Polish, and the major focus lies on the rendition of the degree of lexical emphasis, i.e. lexeme reinforcement (or semantic colouring). It appears that the semantic level, semantic 'quality', may affect the translated text in terms of its semantic reception, especially when the implied recipient is a child. The corpus analysis leads to a conclusion that the lexical emphases found in the analysed translations occur in situations when semantically different or emotionally coloured lexemes appear in the rendered version. The addition of lexemes or modification of their number, e.g. from singular to plural, are commonly applied. The emphasis phenomenon is a significant factor for the quality of the secondary text reception in comparison with the primary text semantic burden.

Keywords: translation of poetry, semantics, text reception, lexical emphasis

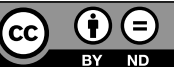

